\title{
Effects of Lidocaine on HT-29 and SW480 Colon Cancer Cells In Vitro
}

\author{
ANIKA C. BUNDSCHERER ${ }^{1}$, MANUELA MALSY ${ }^{1}$, DIANE I. BITZINGER ${ }^{1}$, \\ CHRISTOPH H.R. WIESE ${ }^{2}$, MICHAEL A. GRUBER ${ }^{1}$ and BERNHARD M. GRAF ${ }^{1}$ \\ ${ }^{1}$ Department of Anesthesiology, University of Regensburg, Regensburg, Germany; \\ ${ }^{2}$ Department of Anesthesiology, Herzogin Elisabeth Hospital, Braunschweig, Germany
}

\begin{abstract}
Background: Evidence is growing that the risk of cancer dissemination may be enhanced during the perioperative period. Whether particular anesthetic techniques influence oncological outcome is still under discussion. For pain management, lidocaine can be administered perioperatively by intravenous, intraperitoneal or epidural infusion. Here we investigated the effect of lidocaine on colon carcinoma cell lines (HT-29 and SW480) in vitro. Materials and Methods: ELISA BrdU (Roche) for cell proliferation and FITC Annexin $V$ detection kit (BD Pharming) for apoptosis analysis were applied. Cell-cycle profiles were investigated by flow cytometry. Results: Cellcycle arrest was induced in both cell lines by $1000 \mu \mathrm{M}$ lidocaine, while no inhibition of cell proliferation was detected. Apoptosis decreased in SW480 but not in HT-29 cells. Conclusion: Lidocaine induces cell-cycle arrest in both colon carcinoma cell lines in vitro. The effective drug concentration can be obtained by local infiltration.
\end{abstract}

The perioperative period is believed to be a vulnerable period for cancer dissemination and metastasis (1). Surgical manipulation and perioperative impairment of the immune defense is a fatal combination leading to a high risk for cancer recurrence (2). By mechanical manipulation of tumor tissue or traumatization of tumor vessels, cancer cells can enter the circulation (3). Imbalance between pro- and antiangiogenetic factors and excessive secretion of growth

Presented at DGSS (German Congress of PAIN) 2014, Hamburg, HAI (Berlin Congress of Anesthesiology) 2011, Berlin.

Correspondence to: Anika Bundscherer, MD, Department of Anesthesiology, University of Regensburg, Franz Josef Strauß Allee 11, 93053 Regensburg, Germany. Tel: +49 9419447801, Fax: +49 9419447802, e-mail: anika.bundscherer@ukr.de

Key Words: Lidocaine, local anesthetics, cell proliferation, apoptosis, cell cycle. factors during wound healing can foster the growth of micrometastases and disseminated cancer cells. Another important aspect is the impairment of anticancer surveillance by perioperative immunosuppression (4). Cell-mediated immunity, the first-line anticancer defense mechanism, is attenuated during the first days after surgery. A decreased number of cytotoxic T-cells, T-helper cells and natural killer (NK) cells are detected in the postoperative period. (5) In recent years, it has been debated whether the use of any specific anesthetic technique or the administration of specific drug influences the oncologic outcome after surgery of patients with cancer. (6) Several retrospective studies were performed to investigate the effect of regional anesthesia on cancer progression (7-10). The combination of general anesthesia with epidural or paravertebral anesthesia was associated with better oncological outcome in patients with colon, breast, prostatic and ovarian cancer (7-10).

Results of clinical studies indicate that in addition to epidural infusion, intravenous lidocaine and even intraperitoneal administration of local anesthetics are effective in reducing the perioperative pain level (11-13). In a meta-analysis, the intravenous application of lidocaine was associated with lower pain scores at rest, movement and cough, and reduced requirement for analgesic agents. In addition, ileus recovery time and length of hospital stay decreased (12). Especially in patients undergoing abdominal surgery, perioperative lidocaine infusion demonstrated advantages $(11,14)$. Perioperative instillation and continuous postoperative infusion of intraperitoneal ropivacaine reduced pain and opioid consumption after colectomy. Moreover, early surgical recovery was improved (13).

There is a great variability in human cancer. However, there are some characteristics which the majority of solid cancer types have in common (15). As tumor cell growth is independent of external growth factors and cancer cells are insensitive to inhibitory signals, cancer cell proliferation is an unregulated process. Furthermore, cancer cells are resistant to apoptotic cell death and are able to build up a supportive environment by modulating the tumor stroma. 
According to the consensus statement from the British Journal of Anaesthesia Workshop on Cancer and Anesthesia, further studies are warrant to evaluate the effect of different anesthetic techniques, including intravenously applied lidocaine, on cancer recurrence (6). For this reason, the aim of this study was to investigate if clinically relevant concentrations of lidocaine have anticancer potency. The effects of lidocaine on cell proliferation, cell-cycle progression and apoptosis rate of colon carcinoma cell lines were investigated in vitro.

\section{Materials and Methods}

Agent. Commercially available lidocaine (Sigma-Aldrich, St Gallen, Switzerland) was used for this study. By dissolving lidocaine in standard growth medium, a stock solution was prepared, final concentrations were achieved by diluting with standard growth medium. All solutions were prepared freshly prior to use.

Cell lines. HT-29 and SW480 colon carcinoma cell lines were purchased from the German Collection of Microorganisms and Cell Culture (DSMZ). Standard growth medium (RPMI 1640; Pan Biotech, Aidenbach, Germany) for SW480 and Dulbecco's modified Eagle's medium for HT-29 contained $10 \%$ fetal calf serum (FCS) and $2 \mathrm{mM} \mathrm{L}$-glutamine supplemented with $5 \%$ penicillin plus streptomycin (Sigma Aldrich, St. Louis, MO, USA). SW480 culture medium additionally contained $2 \mathrm{mM}$ sodium pyruvate (Sigma Aldrich). Cells were maintained in monolayer culture and were cultured in a humidified atmosphere with $5 \% \quad \mathrm{CO}_{2}$ at $37^{\circ} \mathrm{C}$. Experiments were performed when cells reached $\sim 80 \%$ confluence.

Cell proliferation. For cell proliferation analysis, an enzyme-linked immunosorbent assay (ELISA) (cell proliferation Elisa BrdU (5bromo-2-deoxyuridine), Roche Applied Science, Mannheim, Germany) was applied. In brief, cells $\left(3-5 \times 10^{3}\right)$ were seeded in 96well plates (Costar, Bodenheim, Germany) and incubated overnight to allow attachment. Cells were then incubated for $48 \mathrm{~h}$ with $0-1000$ $\mu \mathrm{M}$ lidocaine and for $16 \mathrm{~h}$ with BrdU labeling solution. After fixing the cells and denaturating DNA, cells were labeled with anti-BrdUperoxidase solution for $90 \mathrm{~min}$. Cells were washed, incubated with tetramethyl-benzidine substrate for $15 \mathrm{~min}$ and immune complexes were detected by measuring the absorbance at 405 and $490 \mathrm{~nm}$. All tests were performed in duplicates, eight wells per treatment group were used and tests were repeated at least twice.

Cell-cycle analysis. Cell-cycle profiles were measured by cytometry after incubation with lidocaine $(10,100$ and $1,000 \mu \mathrm{M})$ or without (control) for $24 \mathrm{~h}$. Standard culture medium was used for negative control, $5 \mathrm{mM}$ acetylsalicylic acid was used for positive control. Cells were harvested by standard trypsinization and washed twice with cold phosphate-buffered saline (PBS) $/ 5 \mathrm{mM}$ EDTA. $10^{6}$ cells were fixed for $30 \mathrm{~min}$ with $100 \%$ ethanol at room temperature, washed with PBS/5 mM EDTA and treated with $1 \mathrm{mg} / \mathrm{ml}$ RNase A. After 30-min incubation at room temperature, cells were stained with $100 \mu \mathrm{g} / \mathrm{ml}$ propidium iodide (PI) (Sigma-Aldrich). For each sample, 104 cells were measured by flow cytometry using FACS Calibur (BD, Heidelberg, Germany) and Cellquest ${ }^{\mathrm{TM}}$ Pro software (Version 5.2;BD). All tests were repeated at least twice.
Apoptosis analysis. Cells were seeded in $\mathrm{T} 12.5 \mathrm{~cm}^{2}$ cell culture flasks (BD Falcon, Heidelberg, Germany). After $24 \mathrm{~h}$ attachment time, cells were incubated with 0.10 .100 and $1000 \mu \mathrm{M}$ lidocaine in standard growth medium for 3-48 h. Staurosporine at $1 \mu \mathrm{M}$ (Sigma-Aldrich) was used for positive control. Floating cells were preserved by decanting the supernatant. Adherent cells were rinsed with PBS $\left(37^{\circ} \mathrm{C}\right)$ (Sigma-Aldrich) and detached by standard trypsinization. Fluorescein isothiocyanate (FITC) Annexin V Apoptosis detection Kit (BD) was used according to the manufacturer's protocol. In brief, floating and harvested cells were mixed, washed twice with cold PBS and resuspended in binding buffer at a final density of $10^{6}$ cells/ml. FITC Annexin $(5 \mu \mathrm{l})$ and PI $(5 \mu \mathrm{l})$ were added to $100 \mu \mathrm{l}$ of the cell suspension containing $10^{5}$ cells. After gently mixing, the cell suspension was incubated in the dark at room temperature for $15 \mathrm{~min}$. Binding buffer $(400 \mu \mathrm{l})$ was added and cells were analyzed by flow cytometry using FACS Calibur (BD Bioscience) and Cellquest ${ }^{\mathrm{TM}}$ Pro software (BD Bioscience). All tests were performed in duplicates and repeated twice. For data analysis, Fowjo 7.65 (Tree Star, Ashland, OR, USA) was applied.

Statistical analysis. Results are expressed as the mean \pm SD. For comparison between mean values, the non-parametric MannWhitney $U$-test was used. Differences were considered statistically significant at $p<0.05$. IBM SPSS Statistics (V 21; IBM, Armonk, NY, USA) packages were employed for statistical analysis.

\section{Results}

Cell proliferation. In the HT-29 colon carcinoma cell line, treatment with 1-1,000 $\mu \mathrm{M}$ lidocaine for $48 \mathrm{~h}$ did not significantly affect the cell proliferation rate compared to the untreated control. In the SW480 cell line, incubation with $10 \mu \mathrm{M}$ and $100 \mu \mathrm{M}$ lidocaine caused a slight but statistically significant increase in cell proliferation (Figure 1).

Cell-cycle analysis. Incubation with $1,000 \mu \mathrm{M}$ lidocaine for $24 \mathrm{~h}$ significantly increased the fraction of cells in the $\mathrm{G}_{1}$ phase of the cell cycle in both cell lines. Simultaneously the fraction of cells in S phase decreased significantly compared to the untreated control. After treatment with $10 \mu \mathrm{M}$ and $100 \mu \mathrm{M}$ lidocaine, no changes in cell-cycle distribution were detected in either cell line (Table I).

Apoptosis analysis by annexin staining. In SW480 colon carcinoma cells, a decrease in apoptosis rate accompanied by an increased number of vital cells was observed at all concentrations after 3-24 h incubation time (Figure 2a). After $48 \mathrm{~h}$, no difference in apoptosis rate was detected compared to the untreated control. In HT-29 colon carcinoma cells, treatment with 10-1000 $\mu \mathrm{M}$ lidocaine did not cause significant changes in apoptotic cell fraction at any point of time (Figure $2 \mathrm{~b})$. The positive control staurosporine induced a significant increase of apoptotic cells after 16, 24 and $48 \mathrm{~h}$ treatment in both cancer cell lines. 


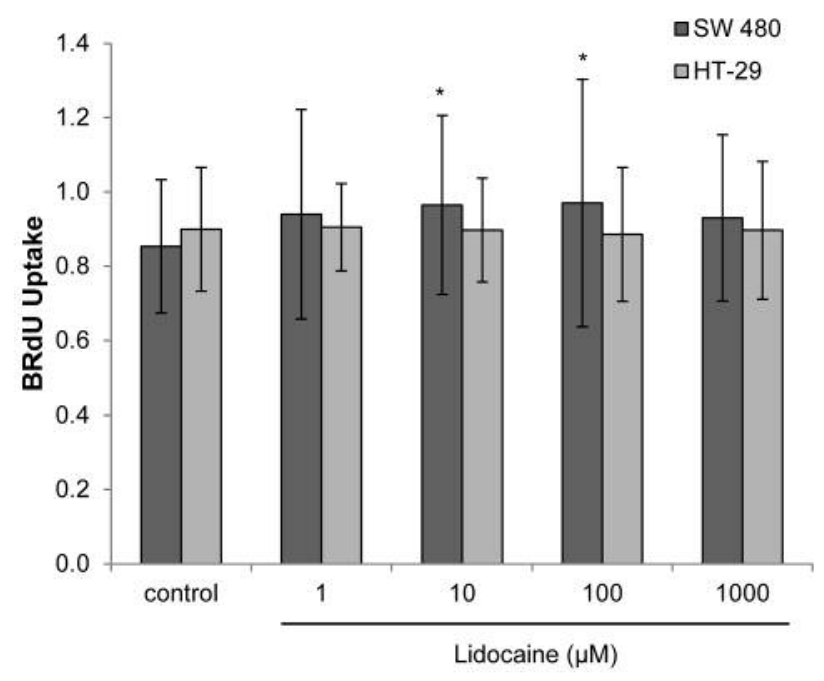

Figure 1. Effect of lidocaine on cell proliferation of HT-29 and SW480 colon carcinoma cell lines. Proliferation was detected by 5-bromo-2deoxyuridine (BrdU) uptake after $48 \mathrm{~h}$ incubation with lidocaine. $*$ Statistically significantly different at $p<0.05$ compared to the untreated control. Data are the mean $\pm S D$.

\section{Discussion}

In this study, we show the induction of cell-cycle arrest by $1,000 \mu \mathrm{M}$ lidocaine in two colon carcinoma cell lines. However, no reduction of cell proliferation was found in SW480 and HT-29 colon carcinoma cells. Martinsson and colleagues showed no growth inhibition by lidocaine in HT-29 cancer cells grown in medium containing 10\% FCS (16). Lidocaine concentrations above $9 \mathrm{mM}$ were needed to affect cell viability in lymphoma cells (17) and the 50\% effective doses for growth inhibition in two thyroid cancer cell lines were $6.8 \mathrm{mM}$ and $7.3 \mathrm{mM}$ (18). In human tongue cancer cells, $400 \mu \mathrm{M}$ lidocaine reduced cell proliferation rate without cytotoxic effects (19). At clinically relevant concentrations, lidocaine and ropivacaine demethylated the DNA in breast cancer cell lines while cell viability was not affected at these concentrations (20).

In our study, 10-1,000 $\mu \mathrm{M}$ lidocaine did not cause changes in the apoptoic rate of the HT-29 colon carcinoma cell line, while in SW480 cells, a decreased number of apoptoic cells was detected after 3-24 h incubation. Lidocaine was shown to induce apoptosis in neuroblastoma $(17,21)$, lymphoma $(17$, 22 ), thyroid (18) and breast cancer (23) cell lines. Evidence is growing that the mitochondrial pathway plays a crucial role in lidocaine-triggered apoptosis. Johnson et al. reported a disruption of mitochondrial membrane potential and the release of mitochondrial cytochrome $c$ into the cytoplasm caused by lidocaine in rat dorsal root ganglion cells (24). In human thyroid cancer cells, similar effects were accompanied by an increase in the apoptosis regulator BCL2-associated X/BCL2
Table I. Effect of lidocaine on cell-cycle distribution. Cell-cycle distribution in SW480 and HT-29 colon cancer cell lines after treatment with 10, 100 and $1000 \mu \mathrm{M}$ lidocaine for $24 \mathrm{~h}$. The cell-cycle distribution was analyzed flow cytometrically after staining with propidium iodide. $*$ Statistically significantly different at $p<0.05$ compared to the untreated control. Data are the mean $\pm S D$.

\begin{tabular}{lcccc}
\hline & & \multicolumn{4}{c}{ Phase (\% of total cells) } \\
\cline { 3 - 5 } Cell line & Treatment & $\mathrm{G}_{1}$ & $\mathrm{~S}$ & $\mathrm{G}_{2}$ \\
\hline \multirow{2}{*}{ SW480 } & Control & $52.2 \pm 4.85$ & $31.85 \pm 2.88$ & $10.26 \pm 0.87$ \\
& $10 \mu \mathrm{M}$ Lidocaine & $51.6 \pm 3.21$ & $32.28 \pm 3.11$ & $10.82 \pm 0.91$ \\
& $100 \mu \mathrm{M}$ Lidocaine & $51.27 \pm 5.03$ & $32.28 \pm 3.13$ & $11.15 \pm 0.94$ \\
& $1000 \mu \mathrm{M}$ Lidocaine & $63.3 \pm 4.09 *$ & $20.97 \pm 1.58^{*}$ & $11.00 \pm 1.53$ \\
HT-29 & Control & $39.77 \pm 3.92$ & $37.05 \pm 3.18$ & $12.05 \pm 1.88$ \\
& $10 \mu \mathrm{M}$ Lidocaine & $43.07 \pm 5.08$ & $34.7 \pm 4.59$ & $12.97 \pm 1.22$ \\
& $100 \mu \mathrm{M}$ Lidocaine & $44.15 \pm 5.98$ & $33.07 \pm 4.58$ & $13.8 \pm 1.57$ \\
& $1000 \mu \mathrm{M}$ Lidocaine & $49.82 \pm 2.39 *$ & $30.07 \pm 2.43 *$ & $11.90 \pm 1.26$ \\
\hline
\end{tabular}

ratio (18). Lack of caspase-9 or overexpression of the antiapoptotic protein BCL2 inhibited apoptosis induction by lidocaine in human Jurkat T-lymphoma cells, while caspase-8 deficiency did not affect the apoptosis rate (22).

These studies were conducted with the aim of investigating the risk of cell damage after spinal anesthesia or local lidocaine infiltration. For this reason, concentrations of lidocaine ranging from $3 \mathrm{mM}$ up to $185 \mathrm{mM}$ were used, which are comparable to $1-5 \%$ lidocaine $(18,24)$. Exposure to lidocaine ranged from $10 \mathrm{~min}(24)$ to $48 \mathrm{~h}(17,18)$.

For perioperative pain therapy in patients undergoing abdominal surgery, lidocaine can be administered via epidural, intravenous or intraperitoneal injection. With a plasma concentration ranging between 1 and $5 \mu \mathrm{g} / \mathrm{ml}(\approx 3.5$ $17.3 \mu \mathrm{M})$, lidocaine levels are comparable after epidural, intravenous or intraperitoneal application (25-28).

In the present study, cell-cycle arrest was detected after treatment with 1,000 $\mu \mathrm{M}$ lidocaine. This concentration is far above the clinically relevant plasma concentration after epidural, intravenous or intraperitoneal application. However, this concentration can be achieved by local injection.

In conclusion, lidocaine caused cell-cycle arrest in HT-29 and SW480 colon carcinoma cell lines in vitro. The effective drug concentration is achievable by local infiltration, but not by epidural or intravenous application. Lidocaine is clinically used as an adjuvant agent in perioperative pain therapy. Further studies are needed to investigate whether this pain therapy regime bears the risk of cancer progression or even exerts anticancer potency in some tumor entities.

\section{Funding}

Regensburger Forschungsfoerderung in der Medizin (ReForM), Faculty of Medicine, University of Regensburg. 

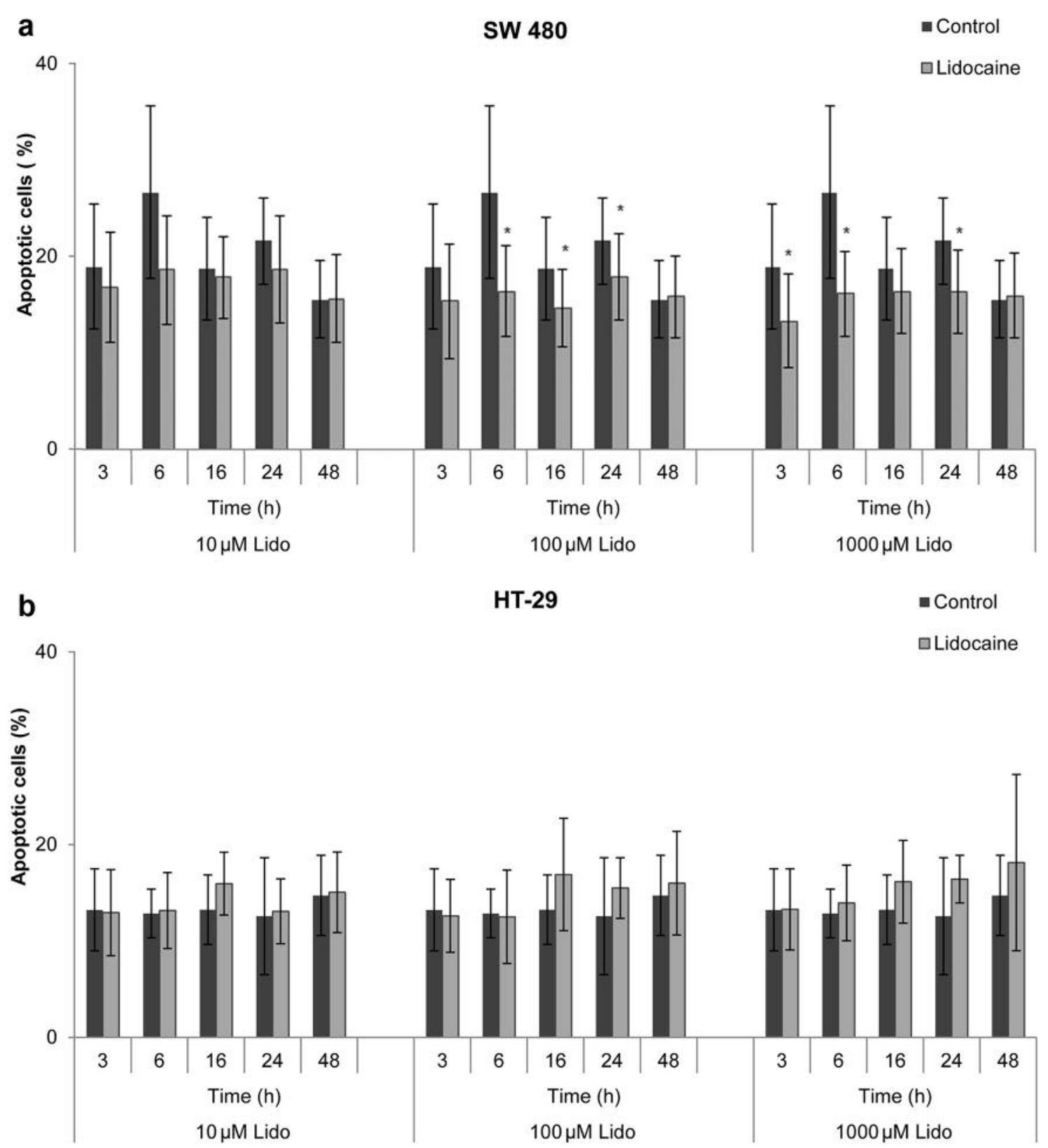

Figure 2. Effect of lodicaine (Lido) on apoptosis: Apoptosis analysis in SW480 (a) and HT-29 (b) colon carcinoma cell lines. After treatment with 10, 100 or $1000 \mu \mathrm{M}$ lidocaine for 3-48 h, cells were stained with annexin $V$ and propidium iodide. *Statistically significantly different at $p<0.05$ compared to the untreated control. Data are the mean $\pm S D$.

\section{Conflicts of Interest}

None declared.

\section{Acknowledgements}

The Authors thank Renate Lange, Sigrid Bamberger, Regina Lindner, Marion Schindler, Ruth Spaeth and Daniel Potschka for excellent technical support. We thank the Regensburger Forschungsfoerderung in der Medizin (ReForM) program of the University of Regensburg for financial support.

\section{References}

1 Gottschalk A, Sharma S, Ford J, Durieux ME and Tiouririne M: Review article: the role of the perioperative period in recurrence after cancer surgery. Anesth Analg 110: 1636-1643, 2010. 
2 Lee JW, Shahzad MM, Lin YG, Armaiz-Pena G, Mangala LS, Han HD, Kim HS, Nam EJ, Jennings NB, Halder J, Nick AM, Stone RL, Lu C, Lutgendorf SK, Cole SW, Lokshin AE and Sood AK: Surgical stress promotes tumor growth in ovarian carcinoma. Clin Cancer Res 15: 2695-2702, 2009.

3 Goldfarb Y and Ben-Eliyahu S: Surgery as a risk factor for breast cancer recurrence and metastasis: mediating mechanisms and clinical prophylactic approaches. Breast Dis 26: 99-114, 2006.

4 Kurosawa S: Anesthesia in patients with cancer disorders. Curr Opin Anaesthesiol 25: 376-384, 2012.

5 Snyder GL and Greenberg S: Effect of anaesthetic technique and other perioperative factors on cancer recurrence. $\mathrm{Br} J$ Anaesth 105: 106-115, 2010.

6 Buggy DJ, Borgeat A, Cata J, Doherty DG, Doornebal CW, Forget P, Gottumukkala V, Gottschalk A, Gupta A, Gupta K, Hales TG, Hemmings HC, Hollmann MW, Kurz A, Ma D, Parat MO, Sessler DI, Shorten G and Singleton P: Consensus statement from the BJA Workshop on Cancer and Anaesthesia. Br J Anaesth 114: 2-3, 2015.

7 Exadaktylos AK, Buggy DJ, Moriarty DC, Mascha E and Sessler DI: Can anesthetic technique for primary breast cancer surgery affect recurrence or metastasis? Anesthesiology 105: 660-664, 2006.

8 Biki B, Mascha E, Moriarty DC, Fitzpatrick JM, Sessler DI and Buggy DJ: Anesthetic technique for radical prostatectomy surgery affects cancer recurrence: a retrospective analysis. Anesthesiology 109: 180-187, 2008.

9 Gupta A, Bjornsson A, Fredriksson M, Hallbook O and Eintrei $\mathrm{C}$ : Reduction in mortality after epidural anaesthesia and analgesia in patients undergoing rectal but not colonic cancer surgery: a retrospective analysis of data from 655 patients in central Sweden. Br J Anaesth 107: 164-170, 2011.

10 de Oliveira GS, Jr., Ahmad S, Schink JC, Singh DK, Fitzgerald $\mathrm{PC}$ and McCarthy RJ: Intraoperative neuraxial anesthesia but not postoperative neuraxial analgesia is associated with increased relapse-free survival in ovarian cancer patients after primary cytoreductive surgery. Reg Anesth Pain Med 36: 271-277, 2011.

11 McCarthy GC, Megalla SA and Habib AS: Impact of intravenous lidocaine infusion on postoperative analgesia and recovery from surgery: a systematic review of randomized controlled trials. Drugs 70: 1149-1163, 2010.

12 Vigneault L, Turgeon AF, Cote D, Lauzier F, Zarychanski R, Moore L, McIntyre LA, Nicole PC and Fergusson DA: Perioperative intravenous lidocaine infusion for postoperative pain control: a meta-analysis of randomized controlled trials. Can J Anaesth 58: 22-37, 2011.

13 Kahokehr A, Sammour T, Shoshtari KZ, Taylor M and Hill AG: Intraperitoneal local anesthetic improves recovery after colon resection: a double-blinded randomized controlled trial. Ann Surg 254: 28-38, 2011.

14 Kranke P, Jokinen J, Pace NL, Schnabel A, Hollmann MW, Hahnenkamp K, Eberhart LH, Poepping DM and Weibel S: Continuous intravenous perioperative lidocaine infusion for postoperative pain and recovery. Cochrane Database Syst Rev 7: CD009642, 2015.
15 Hanahan D and Weinberg RA: Hallmarks of cancer: the next generation. Cell 144: 646-674, 2011.

16 Martinsson T: Ropivacaine inhibits serum-induced proliferation of colon adenocarcinoma cells in vitro. J Pharmacol Exp Ther 288: 660-664, 1999.

17 Kamiya Y, Ohta K and Kaneko Y: Lidocaine-induced apoptosis and necrosis in U937 cells depending on its dosage. Biomed Res 26: 231-239, 2005.

18 Chang YC, Hsu YC, Liu CL, Huang SY, Hu MC and Cheng SP: Local anesthetics induce apoptosis in human thyroid cancer cells through the mitogen-activated protein kinase pathway. PloS one 9: e89563, 2014.

19 Sakaguchi M, Kuroda Y and Hirose M: The antiproliferative effect of lidocaine on human tongue cancer cells with inhibition of the activity of epidermal growth factor receptor. Anesth Analg 102: 1103-1107, 2006.

20 Lirk P, Hollmann MW, Fleischer M, Weber NC and Fiegl H: Lidocaine and ropivacaine, but not bupivacaine, demethylate deoxyribonucleic acid in breast cancer cells in vitro. $\mathrm{Br} \mathrm{J}$ Anaesth 113(Suppl 1): i32-38, 2014.

21 Werdehausen R, Fazeli S, Braun S, Hermanns H, Essmann F, Hollmann MW, Bauer I and Stevens MF: Apoptosis induction by different local anaesthetics in a neuroblastoma cell line. Br J Anaesth 103: 711-718, 2009.

22 Werdehausen R, Braun S, Essmann F, Schulze-Osthoff K, Walczak H, Lipfert $\mathrm{P}$ and Stevens MF: Lidocaine induces apoptosis via the mitochondrial pathway independently of death receptor signaling. Anesthesiology 107: 136-143, 2007.

23 Chang YC, Liu CL, Chen MJ, Hsu YW, Chen SN, Lin CH, Chen $\mathrm{CM}$, Yang FM and Hu MC: Local anesthetics induce apoptosis in human breast tumor cells. Anesth Analg 118: 116-124, 2014.

24 Johnson ME, Uhl CB, Spittler KH, Wang H and Gores GJ: Mitochondrial injury and caspase activation by the local anesthetic lidocaine. Anesthesiology 101: 1184-1194, 2004.

25 Kahokehr A, Sammour T, Vather R, Taylor M, Stapelberg F and Hill AG: Systemic levels of local anaesthetic after intraperitoneal application - a systematic review. Anaesth Intensive Care 38: 623-638, 2010.

26 Koppert W, Ostermeier N, Sittl R, Weidner C and Schmelz M: Low-dose lidocaine reduces secondary hyperalgesia by a central mode of action. Pain 85: 217-224, 2000.

27 Hodgson PS and Liu SS: Epidural lidocaine decreases sevoflurane requirement for adequate depth of anesthesia as measured by the Bispectral Index monitor. Anesthesiology 94 : 799-803, 2001.

28 Shono A, Sakura S, Saito Y, Doi K and Nakatani T: Comparison of $1 \%$ and $2 \%$ lidocaine epidural anaesthesia combined with sevoflurane general anaesthesia utilizing a constant bispectral index. Br J Anaesth 91: 825-829, 2003.

Received February 27, 2017

Revised March 19, 2017

Accepted March 20, 2017 